\title{
Study of Nutrient Foramina of Fibula with Other Long Bones: A Central Rajasthan Study
}

\author{
Anjana mathur ${ }^{1}$, Manish $\mathrm{D}$ sharma ${ }^{2 *}$ \\ 'Senior Professor \& head, ${ }^{*} \mathrm{PG}$ Resident (IIIrd year), \\ Department of Anatomy, J.L.N Medical College, Ajmer, Rajasthan, India.
}

\begin{abstract}
The external opening of the nutrient canal, is usually referred to as nutrient foramina, it has a particular position for each bone. The nutrient artery is the principal source of blood to long bones. Nutrient arteries play an important role in nutrition and growth of the bones particularly during its growth period in the embryo and fetus as well as during early phases of ossification. Detailed data on blood supply of long bones plays a major role in the development of new transplantation and resection techniques in orthopaedics. The present study was conducted in the department of Anatomy, JLN Medical College, Ajmer, Rajasthan. Aiming at knowing the number, position and direction of nutrient foramina of fibula and other long bones including humerus, radius, ulna, and lastly the comparison of data of fibula with other long bones. A total of 150 long bones are taken for study with 25 of each type i.e fibula, femur, tibia, humerus, radius, ulna. Majority of the bones followed the growing end theory. The location of the nutrient foramina is predominant on the anterior aspect of the upper limb long
\end{abstract}

\section{INTRODUCTION}

The external opening of the nutrient canal, usually referred to as the nutrient foramen, has a particular position for each bone. ${ }^{1}$ The nutrient artery is the principle source of blood to a long bone particularly during its active growth period. The artery to the shaft of the long bone is the largest, called the 'Nutrient Artery'. ${ }^{2}$ Bones are structures that adapt to their mechanical environment, and from a fetal age adapt to the presence of naturally occurring holes. These holes or nutrient foramina, allow blood vessels to pass through the bone cortex. ${ }^{3}$

The bones of the leg are the tibia and fibula, the former being developmentally the preaxial bone and therefore corresponding to the radius of the forearm, and the latter corresponding to the ulna, the postaxial bone. ${ }^{4}$ Their direction follows a general adult rule "towards the knee and away from elbow I flee". The nutrient foramen is distinguished from any other foramen by the presence of distinct vascular groove outside the nutrient foramen. The direction of nutrient canal is important to denote the growing end of a bone. ${ }^{5}$ The external opening of the nutrient canal, usually referred to as the nutrient foramen, has a particular position for each bone. ${ }^{6}$ Longia GS et al. ${ }^{7}$ observed that the position of nutrient foramina was on the flexor aspect in their human long bone specimens. It is generally agreed that the vessels which occupy the nutrient foramen are derived from those that took part in the initial invasion of the ossifying cartilage, so that the nutrient foramen was at the site of original centre of ossification. 8,9

Study of relative relationship between the length of bone and bones, and on the posterior aspect of the lower limb long bones. The majority of the bones studied had a single nutrient foramen, which may represent a single source of blood supply.

Keywords: Fibula, Nutrient artery, Nutrient foramen. *Correspondence to:

Dr. Manish D Sharma, A-19 kirti Nagar, Tonk Road, Jaipur, Rajasthan

Email: drmdevsharma@gmail.com

Article History:

Received: 02-05-2016, Revised: 12-05-2016, Accepted: 31-05-2016

\begin{tabular}{|l|c|}
\hline \multicolumn{2}{|c|}{ Access this article online } \\
\hline $\begin{array}{l}\text { Website: } \\
\text { www.jimrp.com }\end{array}$ & Quick Response code \\
\hline DOI: & \\
10.21276/ijmrp.2016.2.3.034 & \\
\hline
\end{tabular}

distance of nutrient foramen from either ends is useful in calculating the length of a long bone from a given fragment, which is important in medico-legal and anthropological work. From the length of the long bones height of an individual can be reconstructed. ${ }^{10}$

The nutrient artery is the principal source of blood supply to a long bone and is particularly important during its active growth period in the embryo and fetus, as well as during the early phase of ossification. ${ }^{11}$ During childhood, the nutrient arteries provide 70 $80 \%$ of the intraosseous blood supply to long bones, when this supply is compromised, medullary bone ischemia occurs with less vascularization of the metaphysis and growth plate. ${ }^{12}$

Detailed data on the blood supply to the long bones and the association with the areas of bone supplied has been continued to be a major factor in the development of new transplantation and resection techniques in orthopaedics. ${ }^{13}$

An understanding of the location and the number of the nutrient foramina in long bones is therefore important in orthopedic surgical procedures such as joint replacement therapy, fracture repair bone grafts and vascularized bone microsurgery as well as medico legal cases.

Importance of nutrient foramen is relevant to fracture treatment. Combined periosteal and medullary blood supply to the bone cortex helps to explain the success of nailing of long bone fractures particularly in the weight bearing like femur and tibia and uses of vascularised fibula bone in bony defects due to trauma. 


\section{AIMS AND OBJECTIVES}

The study is undertaken, as the knowledge of nutrient foramina of long bones is useful for anthropologists, anatomists, forensic experts, orthopedic and plastic surgeons for fibula graft and microvascular bone transfer. The morphometric analysis of the position of the nutrient foramen of the fibula will help in harvesting vascularized graft of the bone, to preserve the circulation within bone, also to reconstruct and close the bone defects.

Following parameters were studied in male and females and tabulated separately for the present study:

1. Total length: length of each long bone was measured with osteometric board.

2. Number of nutrient foramen: with magnifying lens.

3. Direction and obliquity of nutrient foramen

4. Distance of nutrient foramen from upper end: measured with Vernier calipers.

5. Distance of nutrient foramen from lower end: measured with Vernier calipers.

6. Position of nutrient foramen according to the segments: To locate the exact position of nutrient foramen and to study its direction, the shaft of each long bone was divided in to various segments. First total length of each long bone was measured by Osteometric board then it was divided into various equal segments by Vernier calipers. For the sake of convenience Humerus and femur were divided in to 6 segments while other bones viz. radius, ulna, tibia, fibula were divided in to 3 segments.

Table 1: Numbers of Foramen in 150 Long Bones

\begin{tabular}{lcccc}
\hline Long bones & \multicolumn{4}{c}{ No. Of foramina } \\
\hline Total & 0 & 1 & 2 & 3 \\
150 & 11 & 119 & 15 & 5 \\
\hline
\end{tabular}

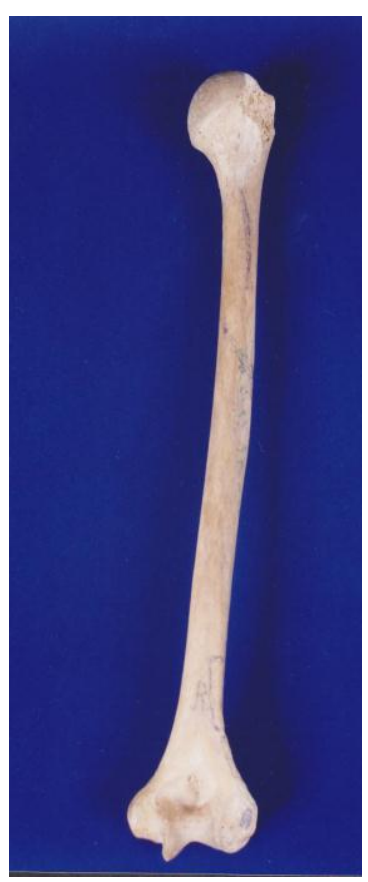

Fig 1: Humerus- foramen in spiral groove

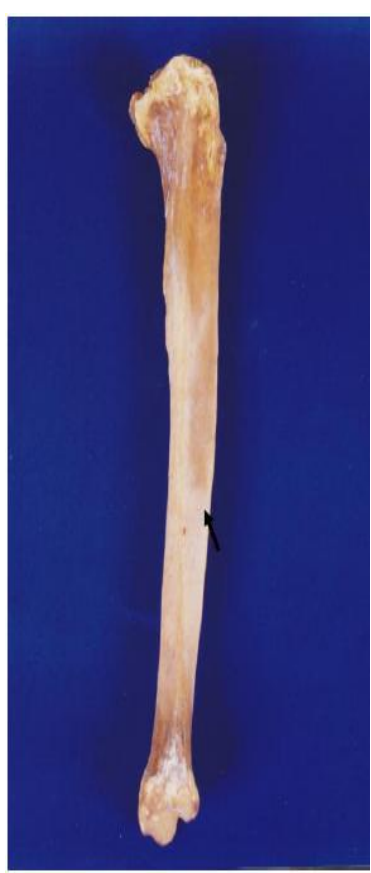

Fig 2: Foramen of tibia is directed towards the knee
Table 2: Direction of Foramen in 150 Long Bones

\begin{tabular}{|c|c|c|}
\hline \multirow[t]{2}{*}{ Name of Bones } & \multicolumn{2}{|c|}{$\begin{array}{l}\text { Figures indicate the number of } \\
\text { bones }\end{array}$} \\
\hline & $\begin{array}{l}\text { Towards the } \\
\text { growing end }\end{array}$ & $\begin{array}{c}\text { Away from the } \\
\text { growing end }\end{array}$ \\
\hline $\begin{array}{l}\text { Long Bones of } \\
\text { the limbs (150) }\end{array}$ & 3 & 136 \\
\hline
\end{tabular}

Table 3: Location of Foramen on Various Surfaces of Shaft of Long Bones

\begin{tabular}{|c|c|c|c|c|}
\hline \multirow{2}{*}{$\begin{array}{l}\text { Sr. } \\
\text { no }\end{array}$} & \multirow{3}{*}{$\begin{array}{l}\text { Name of } \\
\text { bones }\end{array}$} & \multicolumn{3}{|c|}{ (Figures indicate numbers of foramen) } \\
\hline & & \multirow[t]{2}{*}{ Expected site } & \multicolumn{2}{|c|}{ Variant site } \\
\hline & & & 1 & 2 \\
\hline \multirow[t]{2}{*}{1} & Femur & Medial side of Linea aspara & Lateral side of linea aspara & Anterior Surface \\
\hline & & 38 & 3 & 2 \\
\hline \multirow[t]{2}{*}{2} & Tibia & Posterior or Postero Lateral - & Lateral Surface & \\
\hline & & 26 & - & - \\
\hline \multirow[t]{2}{*}{3} & Fibula & Posterior Surface & Medial Surface & Lateral Surface \\
\hline & & 21 & 2 & - \\
\hline \multirow[t]{2}{*}{4} & Humerus & Antero- Medial surface & Spiral Groove & Antero- Lateral Surface \\
\hline & & 27 & 6 & - \\
\hline \multirow[t]{2}{*}{5} & Radius & Anterior Surface & Posterior surface & \\
\hline & & 22 & 1 & - \\
\hline \multirow[t]{2}{*}{6} & Ulna & Anterior surface & Posterior surface & \\
\hline & & 24 & 24 & \\
\hline 7 & Total & 158 & 36 & 2 \\
\hline
\end{tabular}

\section{MATERIALS AND METHODS}

For the present study a total 150 long bones of unknown age and sex belonging to the skeletal collection of the department of anatomy, J.L.N Medical College, Ajmer taken for the study.

Exclusion criteria: bones with deformities and fractured bones are excluded from this study
Following long bones were taken for the present study: Femur, Tibia, Fibula, Humerus, Radius, and Ulna.

Instruments used for the study:

1. Hand lens: Used to locate nutrient foramina.

2. Osteometric board: Used to measure the length of long bones.

3. Vernier calipers: Used to measure diameter of the long bones. 
Table 4: Lengthwise Distribution of Foramina on the Shaft of Long Bones

\begin{tabular}{llccc}
\hline Sr. & Name of & \multicolumn{3}{c}{ (Numbers of foramen) } \\
\cline { 3 - 5 } no & bones & $\begin{array}{c}\text { Upper } \\
\text { third }\end{array}$ & $\begin{array}{c}\text { Middle } \\
\text { third }\end{array}$ & $\begin{array}{c}\text { Lower } \\
\text { third }\end{array}$ \\
& & 22 & 15 & 6 \\
$\mathbf{1}$ & Femur & 25 & - & - \\
$\mathbf{2}$ & Tibia & - & 16 & 2 \\
$\mathbf{3}$ & Fibula & - & 22 & 9 \\
$\mathbf{4}$ & Humerus & 2 & 3 & - \\
$\mathbf{5}$ & Radius & 19 & 5 & - \\
$\mathbf{6}$ & Ulna & 19 & 61 & 17 \\
$\mathbf{7}$ & Total & 87 & & \\
\hline
\end{tabular}

\section{RESULTS \& DISSCUSION}

In embryonic period all the nutrient arteries course caudally. This is true in hemodynamic point of view to force the blood from cephalic to caudal side. This agrees with adult rules "towards the knee and away from elbow". This is said to be due to unequal growth of the ends of the long bones.

The arrangement of diaphyseal nutrient foramen in long bones usually follows a definite pattern. Position is constant and seen on flexor surfaces. The direction of nutrient foramina in human long bones is directed away from the growing end. This is due to one end of long bone is growing faster than the other end.

The present study confirms this (table $1 \& 2$ ). Only 3 of limb bones defied the growing end theory. The only probable explanation could be that there must not have been much difference in the longitudinal growth of bone at both the ends.

In the present study 11 of long bones had no nutrient foramen, the maximum incidence was in fibula (followed by femur. Humerus showed absence of foramen but in lesser proportions. Again fibula showed maximum variation in direction of nutrient canal i.e. towards the growing end. Both the variation is higher than previous studies.

\section{CONCLUSION}

We can conclude from present study that, Out of the 150 bones studied

1. 119 bones had single foramen, 11 bones had no nutrient foramen. This suggests that in case of obliteration of nutrient foramen the epiphysial artery might have taken up the charge of supplying the bone.
2. The location of the foramina on the surface of the shaft correlates with the expected site except clavicle where it was seen on posterior surface than the expected inferior surface.

\section{REFERENCES}

1. Fraizer, Ernest J. The Anatomy of Human Skeleton 4th Edition (1964).p5

2. B.D.Chaurasia's - Hand book of General Anatomy 3rd Ed., Page 35-36

3. Gray's Anatomy 38th Ed. (1992) p469

4. Chhatrapati, D. N. andj Mishra, B. D. (1967).

5. Position of nutrient foramen on the shaft of human long bones, J. Anat. Socy. India 16 54-63

6. Lutken, $\mathrm{P}$ (1950) Position of Nutrient foramina in man. Act Anat. 9, 57-68

7. M Patake and V R Mysorekar ( 1976) J. Anat. (1977), 124, 2, pp. 299-304

8. Ujwal, Z. S. (1962) Nutrient canal of long bones, Uni. Of Rajasthan Studies, 6, 39-43.

9. Gray's- A text book of human anatomy, 38th edition.page 257.

10. Kate B.R, nutrient foramina in human long bones, J. Anat. Soc. Of India, 1970; 20, 141

11. LutkenPoul. Investigation into position of nutrient foramen \& direction of the vessel canals in the shaft of the humerus and femur in man. Acta. Anat.1950; 9: 57-68.

12. Payton $C G$, The position of the nutrient foramen and direction of the nutrient canal in the long bones of the madder-fed pig, J Anat, 1934, 68(Pt 4):500-510.

13. Longia GS, Ajmani ML, Saxena SK, Thomas RJ, Study of diaphyseal nutrient foramina in human long bones, ActaAnat (Basel), 1980, 107(4):399-406.

\section{Source of Support: Nil. Conflict of Interest: None Declared.}

Copyright: (c) the author(s) and publisher. IJMRP is an official publication of Ibn Sina Academy of Medieval Medicine \& Sciences, registered in 2001 under Indian Trusts Act, 1882.

This is an open access article distributed under the terms of the Creative Commons Attribution Non-commercial License, which permits unrestricted non-commercial use, distribution, and reproduction in any medium, provided the original work is properly cited.

Cite this article as: Anjana mathur, Manish D sharma Study of Nutrient Foramina of Fibula with Other Long Bones: A Central Rajasthan Study. Int J Med Res Prof. 2016; 2(3):155-57. 